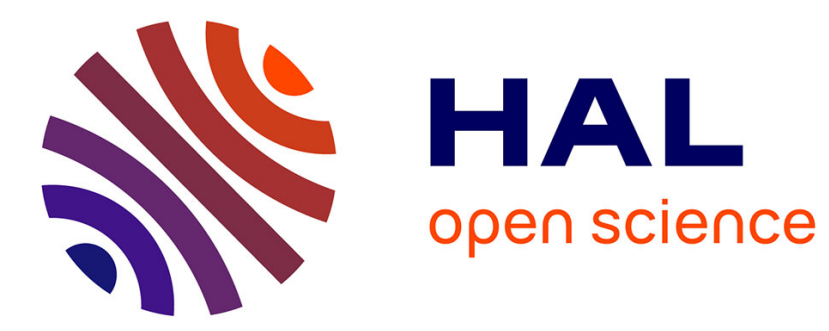

\title{
Defoliation by processionary moth significantly reduces tree growth: a quantitative review Jacquet, Orazio, Jactel
}

\section{To cite this version:}

Jacquet, Orazio, Jactel. Defoliation by processionary moth significantly reduces tree growth: a quantitative review. Annals of Forest Science, 2012, 69 (8), pp.857-866. 10.1007/s13595-012-0209-0 . hal-00930858

\section{HAL Id: hal-00930858 https://hal.science/hal-00930858}

Submitted on 1 Jan 2012

HAL is a multi-disciplinary open access archive for the deposit and dissemination of scientific research documents, whether they are published or not. The documents may come from teaching and research institutions in France or abroad, or from public or private research centers.
L'archive ouverte pluridisciplinaire HAL, est destinée au dépôt et à la diffusion de documents scientifiques de niveau recherche, publiés ou non, émanant des établissements d'enseignement et de recherche français ou étrangers, des laboratoires publics ou privés.

$$
\text { Copyright }
$$




\title{
Defoliation by processionary moth significantly reduces tree growth: a quantitative review
}

\author{
Jean-Sébastien Jacquet • Christophe Orazio • \\ Hervé Jactel
}

Received: 10 December 2011 / Accepted: 9 April 2012 /Published online: 4 May 2012

(C) INRA / Springer-Verlag France 2012

\begin{abstract}
- Context Forests are important carbon sinks, but increasing temperatures may favour increases in insect populations, resulting in greater damage to trees. This, in turn, would lead to lower levels of carbon sequestration, intensifying global warming.

- Aim It is therefore important to predict the impact of insect defoliation on tree growth accurately. The main insect defoliators of conifers in Southern Europe and North Africa are pine and cedar processionary moths (Lepidoptera, Thaumetopoeidae).

- Method We conducted a meta-analysis based on 45 study cases, to estimate the effect of processionary moth defoliation on tree growth.

- Result Overall, processionary moth defoliation had a significant impact on tree growth, regardless of the tree and moth species considered. Mean relative tree growth loss increased with the rate of defoliation levelling out at ca. $50 \%$; it was significantly larger for young than for old trees.

- Conclusion These results suggest that estimates of processionary moth defoliation could easily be incorporated into tree growth models, to predict the effect of processionary moth outbreaks on carbon sequestration in Mediterranean forests.
\end{abstract}

\section{Handling Editor: Francois Lieutier}

Contribution of the co-authors Jean-Sébastien Jacquet, Christophe Orazio and Hervé Jactel: conceived the ideas.

Jean-Sébastien Jacquet: collected the data.

Jean-Sébastien Jacquet and Hervé Jactel: analysed the data.

Jean-Sébastien Jacquet and Hervé Jactel: led the writing.

J.-S. Jacquet $(\bowtie) \cdot$ H. Jactel

Laboratory of Forest Entomology \& Biodiversity,

INRA-UMR1202 BIOGECO,

33612 Cestas, France

e-mail: jacquet@pierroton.inra.fr

C. Orazio

EFI-Atlantic,

33612 Cestas, France
Keywords Meta-analysis - Thaumetopea - Pinus · Cedrus · Defoliation · Growth

\section{Introduction}

Forest ecosystems are major terrestrial carbon sinks (Hyvönen et al. 2007). In Europe, carbon sequestration in forests has increased in recent decades, mostly due to sustained increases in woody biomass (Luyssaert et al. 2010). However, some of this biomass is lost through natural disturbances, such as forest fires, windfalls and insect damage (Nabuurs et al. 2008). In the context of climate change, the predicted increase in net primary production (Nemani et al. 2003) due to higher temperatures and $\mathrm{CO}_{2}$ concentrations may therefore be offset by changes in the frequency and intensity of biotic disturbances (Logan et al. 2003; Netherer and Schopf 2010). Early signs of global warming recently triggered a large-scale outbreak of mountain pine beetle in British Columbia (Bentz et al. 2010) resulting in the death of millions of trees and converting the pine forest from a carbon sink to a source of atmospheric carbon (Kurz et al. 2008). Insect defoliators are likely to have the same impact on forest ecosystems (Dymond 2010). In the shorter term, insect defoliation may also result in lost timber production (Alfaro 1991; Twery 1990). There is therefore a need to improve our knowledge of the consequences of insect defoliation for tree growth and carbon sequestration (Pinkard et al. 2011).

Due to their faster growth, conifers sequester carbon more effectively than broad-leaved species (Hyvönen et al. 2007). However, the defoliation of conifers by insect herbivores may have more severe effects on tree growth (Parsons et al. 2003), particularly because, unlike broad-leaved trees (and larch), they display no reflush growth after foliage consumption (Wainhouse 2005). Heavy defoliation of pine, 
spruce or larch can result in a decrease in stem growth of more than $50 \%$ (Kulman 1971) and the amount of this reduced growth is thought to be linearly proportional to defoliation intensity (Kulman 1971). However, this relationship may be affected by additional factors, such as site conditions, stand age and density, recurrence and time of defoliation (Wainhouse 2005).

The main insect defoliators of conifers in Southern Europe and North Africa are the pine or cedar processionary moths (Lepidoptera, Thaumetopoeidae): Thaumetopoea pityocampa (Dennis and Schiff.), Thaumetopoea wilkinsoni (Tams), Thaumetopoea bonjeani (Powel) and Traumatocampa ispartaensis (Doganlar and Avc1). T. pityocampa is oligophagous on pines and cedars in Mediterranean countries (Devkota and Schmidt 1990; Masutti and Battisti 1990). T. wilkinsoni occurs in the eastern part of the Mediterranean Basin (in Turkey, for example) and its main hosts are Pinus brutia, Pinus halepensis and Pinus nigra (Halperin 1990). T. bonjeani is present in North Africa, where it feeds principally on Cedrus sp. (Gachi et al. 2005). The cedar processionary moth, previously known as Thaumetopoea solitaria (Freyer), has been observed in Turkey since 1975 and was identified as a new species named T. ispartaensis in 2001. T. ispartaensis is one of the most dangerous pests of Cedrus libani in the Middle East (Avcí 2003).

The processionary moth larvae prefer to feed on mature needles but may also feed on young needles, potentially resulting in defoliation of up to $100 \%$ of crown volume. Defoliation decreases the activity of needles and their availability for photosynthesis, resulting in significant impact on tree growth (Hodar et al. 2003). Severe, repeated defoliation may even lead to the death of the tree, particularly if the tree is young or soil conditions are poor, because trees weakened by defoliation are more susceptible to secondary pests, such as bark beetles. In the last decade, it has been shown that $T$. pityocampa is spreading towards higher latitudes and altitudes, probably due to the global warming (Battisti et al. 2005; Robinet et al. 2007). For both peri-Mediterranean forests and more northern pine forests that are potentially susceptible to invasion, it is therefore important to better predict the impact of processionary moth damage on ecosystem functioning.

Several studies have evaluated the loss of tree growth due to processionary moth defoliation (Table 1). However, as for many other insect defoliators (Wainhouse 2005), many different methods have been used to quantify these losses. These methods have included the measurement of annual rings (i.e. dendrochronology), comparing tree circumference, height or volume between defoliated and unaffected trees or comparing growth in the same tree before and after attacks. This diversity of methodological approaches prevents generalisations regarding the patterns of tree growth in response to processionary moth defoliation. Moreover, the lack of consistency in estimates of defoliation rate and the use of different tree species of different ages in these studies makes it difficult to draw firm conclusions about the relationship between growth loss and defoliation severity. We circumvented these problems, by carrying out a metaanalysis of existing studies to address the question of the impacts of processionary moth defoliation on pine or cedar growth. Meta-analysis is based on the use of a set of statistical tools to combine the outcomes of independent studies for evaluations of the overall effect of a particular factor and for assessing the influence of covariates on this effect (Gurevitch and Hedges 1999). Our main objectives were: (1) to determine whether processionary moth defoliation significantly effects tree growth, (2) to determine whether this effect increased significantly with the intensity of defoliation and (3) to investigate whether growth responses to processionary moth defoliation differed between young and mature trees.

\section{Materials and methods}

\subsection{Data collection}

We searched for studies investigating the effect of pine processionary moth defoliation on tree growth in online bibliographic databases (ISI Web of Knowledge and Google Scholar). Keyword searches were conducted with various combinations of relevant terms, such as: Pinus or Cedrus or pine or cedar, processionary or Thaumetopoea, defoliation or damage and radial or diameter or circumference or height or volume or growth. We also searched the references cited in relevant publications. Studies were included in the meta-analysis if they met the following four criteria:

1. Tree growth, estimated with circumference, height or volume variables, was compared between naturally defoliated and unaffected (control) trees. We excluded studies dealing with artificial defoliation because artificial defoliation might not correctly mimic the natural process of processionary moth defoliation in terms of timing and needle choice (Quentin et al. 2010).

2. Defoliation rate was estimated as percent defoliation, stratified into classes.

3. The mean of the growth response variable, a measure of its variance and the sample size for both defoliated and control trees were reported in the text or could be determined by the digitisation of graphs.

4. The reported paired comparison of growth, between defoliated and control trees, was made with the same experimental or observational protocol, on the same date and in the same region. 


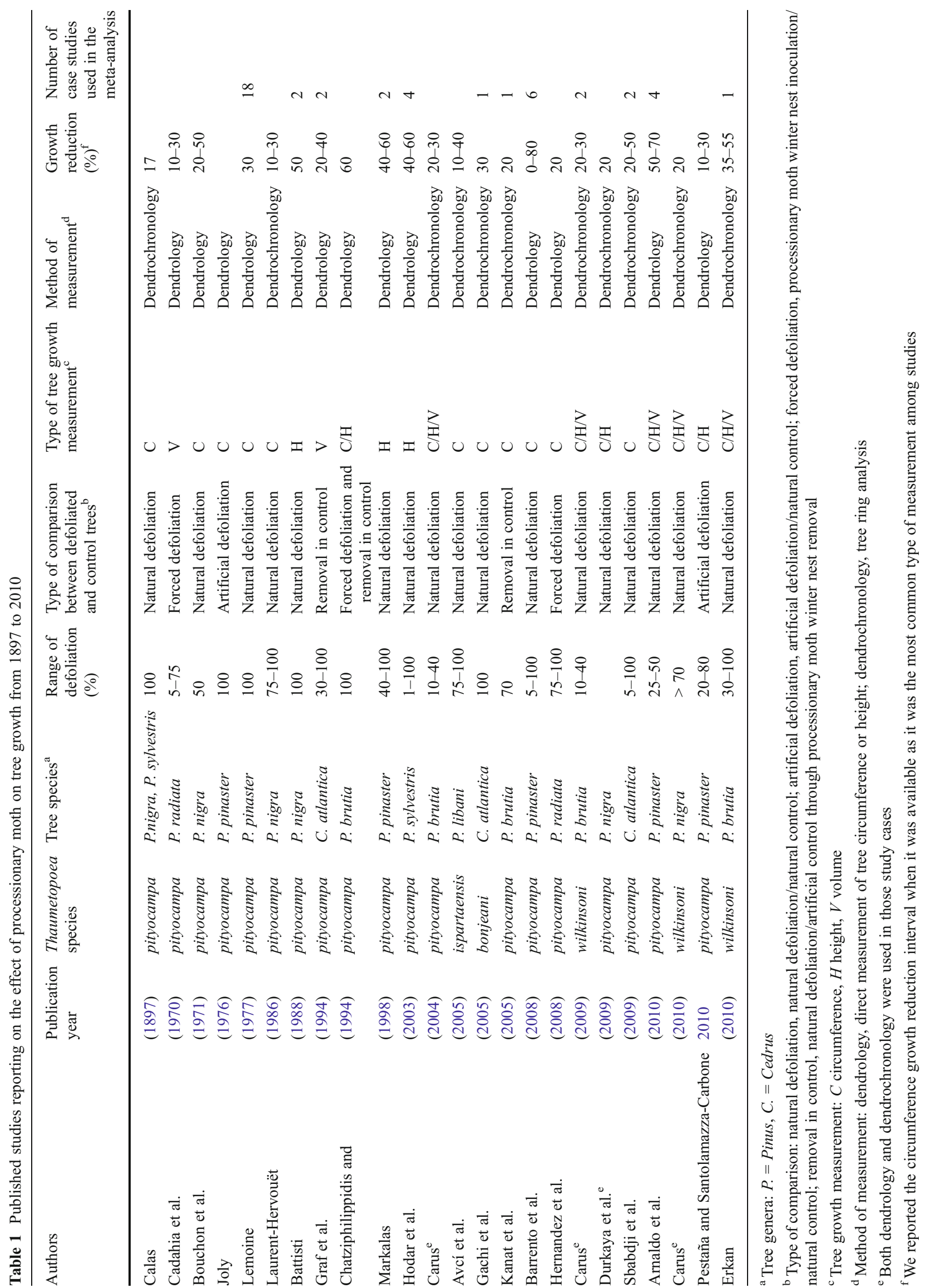


Our literature search identified 24 published studies describing the effect of processionary moth on tree growth. Six of these studies had insufficient statistical data, four lacked information about defoliation rate and two were based on artificial defoliation (Table 1). We rediscovered the archived data for Lemoine's (1977) study, making it possible to distinguish between two independent sampled stands. This meta-analysis was therefore based on 45 pairwise comparisons derived from 12 publications or reports published between 1977 and 2010.

\subsection{Calculating effect sizes and defining explanatory variables}

The effect of processionary moth defoliation on tree growth was estimated by using the $\log$ response ratio $\ln R$ (Eq. 1) as standardised effect size for each pairwise comparison (Hedges et al. 1999). The use of $\ln R$ (rather than Hedges' $d$ or another measurement of effect size) has recently become more common in biological studies because it assumes that effects can be multiplicative and is less sensitive to error than other methods (Morris et al. 2007). The variance of $\ln R\left(v_{\ln R}\right)$ was calculated as in Eq. (2) and the inverse of this variance was used as the weighting in calculations of weighted means (Hedges et al. 1999). A negative value of $\ln R$ indicates a growth loss in defoliated trees (less growth in defoliated trees than in control, unaffected trees).

$$
\ln R=\ln \left(\frac{\bar{X}_{\mathrm{DEF}}}{\bar{X}_{\mathrm{CTL}}}\right)
$$

where $\bar{X}_{\mathrm{DEF}}$ is the mean growth measurement for defoliated trees and $\bar{X}_{\text {СтL }}$ is the mean growth measurement for unaffected, control trees.

$v_{\ln R}=\frac{\left(\sigma_{\mathrm{CTL}}\right)^{2}}{N_{\mathrm{CTL}}\left(\bar{X}_{\mathrm{CTL}}\right)^{2}}+\frac{\left(\sigma_{\mathrm{DEF}}\right)^{2}}{N_{\mathrm{DEF}}\left(\bar{X}_{\mathrm{DEF}}\right)^{2}}$

where $N$ is the sample size and $\sigma$ is the standard deviation.

Because the effect size is a ratio, it has no unit. It is thus theoretically possible to combine studies reporting different types of growth measurements. However, radial and height growth may respond differently to processionary moth defoliation. We therefore assessed the effect of the type of growth measurement used on $\ln R$. Both circumference and height growth data were available for the same trees in six papers accounting for 11 mean values per defoliation class (Chatziphilippidis and Avtzis 1994; Carus 2004, 2009, 2010, Durkaya et al. 2009; Pestaña and SantolamazzaCarbone 2010). A simple linear regression analysis was used to compare mean $\ln R$ values per class of defoliation for circumference and height. It showed that there was a highly significant correlation between the two values of $\ln R$ ( $\left.n=11, F=212.2, R^{2}=0.91, P<0.0001\right)$ which were almost equal to each other ( $\left.\ln R_{\text {cir }}=1.1 \ln R_{\text {height }}\right)$. We therefore pooled studies reporting either circumference or height losses in the same dataset.

For studies reporting tree growth estimates for several years, we used only the data for the first year. Two independent experiments (different stands or sites) reported in the same paper were considered as two separate comparisons.

We split the dataset into classes for tree age and percentage of defoliation. Trees were considered 'young' if they were less than 15 years old and 'old' if they were greater than 15 years old. We defined four classes of processionary moth defoliation rate: class 1, 5-24\%; class 2, 25-49\%; class 3, 50-74\%; and class $4,75-100 \%$. In many cases, groups of trees with different rates of defoliation were compared with the same control group (unaffected trees) within a given study. These comparisons are not truly independent. To account for this problem of multiple comparisons, we used the method proposed by Borenstein et al. (2009). We collapsed the data from all groups of defoliated trees to generate a combined sample size, mean and standard deviation. We then calculated a new effect size for a comparison of the control group with the new merged group. This reduced the entire dataset to 15 fully independent comparisons, for which a new meta-analysis was carried out. The weighted mean of growth loss obtained with the complete dataset $(-43 \%)$ was very similar to the grand mean effect size calculated with the reduced set of independent studies $(-0.38 \%)$ and was within the confidence interval for the reduced set of independent studies $(-26$ to $-48 \%)$. We therefore decided to use the complete dataset with 45 pairwise comparisons, to ensure that a maximum of information was retained and to maximise statistical power in tests for the effect of covariates, such as the rate of defoliation.

We combined effect sizes across all comparisons, using the random effect model (Gurevitch and Hedges 1993) to calculate a weighted mean of growth loss (i.e. the grand mean effect size, $\left.E_{++}\right)$. Because individual studies did not have similar sample sizes, and because the variance of effect size is a function of sample size, it was necessary to calculate a weighted average of effect sizes to estimate cumulative effect size for our sample of studies (Eq. 3)

$E_{++}=\frac{\sum_{i=1}^{n} w_{i} \ln R_{i}}{\sum_{i=1}^{n} w_{i}}$

with $w_{i}=\frac{1}{v_{\ln R_{i}}}$.

The mean effect size was considered statistically significant if its bias-corrected bootstrap confidence interval (CI), estimated with 9,999 iterations, did not include zero. 
We used a mixed-effect model to assess between-class heterogeneity (for each covariate) and to evaluate the significance of the class effect (Gurevitch and Hedges 1999), assuming a fixed effect across classes and a random effect within classes (Borenstein et al. 2009). The weighted mean effect size $E_{j}$ (Eq. 4 ) and a bias-corrected bootstrap confidence interval were then calculated for each class of covariate (tree age and defoliation rate).

$E_{j}=\frac{\sum_{i=1}^{k_{j}} w_{i j} \ln R_{i j}}{\sum_{i=1}^{k_{j}} w_{i j}}$

We calculated the variation in effect size explained by the categorical model ( $Q_{\text {Between }}$ or $\left.Q_{\mathrm{B}}\right)$. This between-class heterogeneity was tested against a $\mathrm{Chi}^{2}$ distribution, to evaluate the significance of the class effect. We back-transformed effect size values with the exponential function to provide a direct estimate of relative growth loss as a percentage of mean growth in unaffected trees.

The publication bias problem was addressed by calculating a fail-safe sample size corresponding to an estimate of the number of studies with a null effect size that we would need to add to the analysis to render the result of the metaanalysis non-significant. The weighted method proposed by Rosenberg (2005) was used to calculate the fail-safe number for our dataset, and this number was then compared with Rosenthal's conservative critical value of $5 n+10$, where $n$ is the total number of comparisons (Rosenberg et al. 2000). All meta-analyses were carried out with METAWIN 2.0 software (Rosenberg et al. 2000).

\section{Results}

The qualitative examination of all retrieved published papers on the effects of processionary moth defoliation indicated that, in all but one case, tree growth was reduced by defoliation (Table 1). However, the relative growth loss attributed to processionary moth defoliation greatly varied between studies, and even for complete defoliation (100\%), it ranged from 20 to $80 \%$ (Table 1).

Our quantitative review (meta-analysis) gave less ambiguous results. It clearly revealed that defoliation by processionary moth caterpillars resulted in a significant decrease in tree growth. The grand mean effect size was $-0.55(\mathrm{CI}=-0.67$ to -0.45$)$, indicating a mean growth loss of $43 \%(\mathrm{CI}=36$ to $49 \%$ ) with respect to unaffected trees. The weighted fail-safe sample size was 55,265 , about 235 times larger than the critical value of $235((5 \times 45)+10)$. Thus, these results are unlikely to be affected by publication bias. In all but 2 of the 45 cases, individual growth rates were negative (Fig. 1). The two cases of a positive effect size, indicating greater growth in defoliated than in unaffected trees, corresponded to the same study (Barrento et al. 2008) and concerned 10-25-year-old trees with 1-25\% of defoliation by $T$. pityocampa. The tree growth response to defoliation by $T$. bonjeani and T. wilkinsoni fell within the range of variation for the tree growth response to defoliation by the more common species T. pityocampa.

\subsection{Effects of percent defoliation}

Percentage defoliation had a highly significant effect on growth loss in defoliated trees $\left(d f=3, Q_{\mathrm{B}}=11.7\right.$ and $\left.P=0.01\right)$.
Fig. 1 Mean growth loss (as a percentage of growth in control trees) in trees defoliated by three species of processionary moth

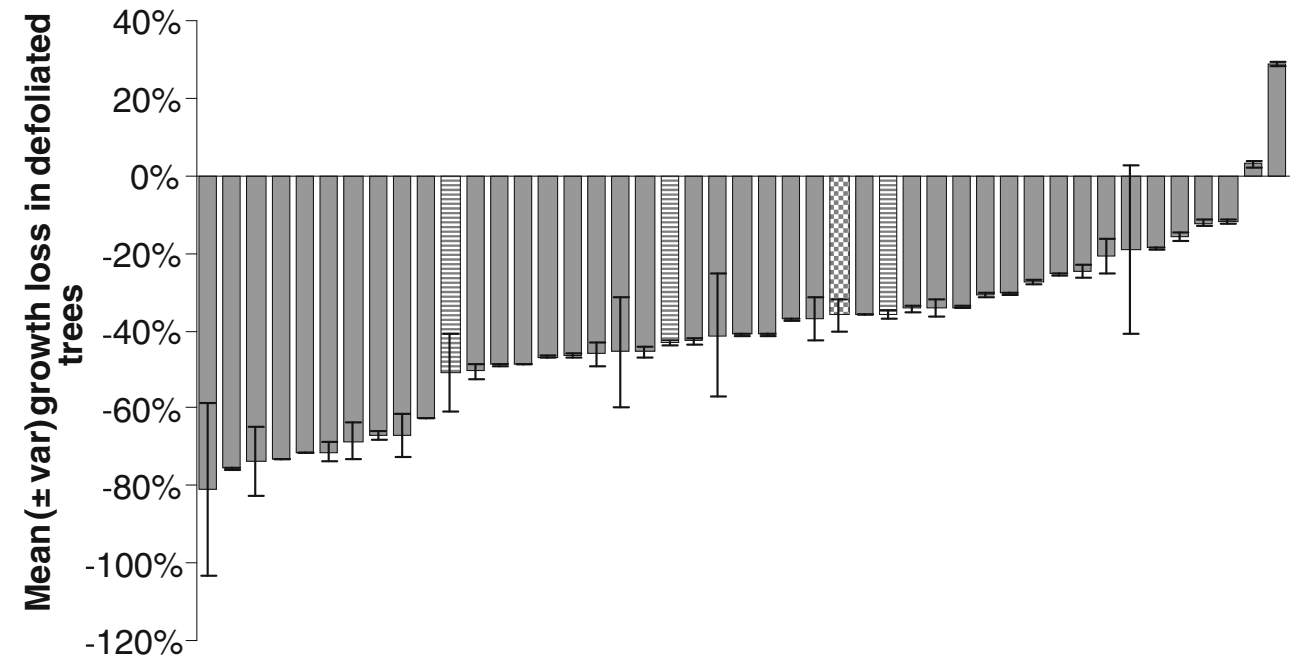

study cases

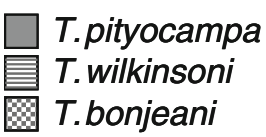


The mean effect size was negative and significantly different from zero for all defoliation rate classes, and its magnitude increased with the rate of defoliation. However, the effect of defoliation on growth loss seemed to level out from defoliation rates of $50 \%$ on (Fig. 2). Low rates of defoliation (5-24\%) resulted in a growth loss of about $20 \%$, whereas severe defoliation $(>50 \%)$ induced growth losses of almost $50 \%$.

\subsection{Effect of tree age}

We tested the effect of tree age hierarchically within each class of processionary moth defoliation rate. We found a significant effect of tree age on tree growth response to processionary moth defoliation within the 5-24\% class $\left(d f=1, Q_{\mathrm{B}}=6.4, P=0.03\right)$ and the $75-100 \%$ class $(d f=1$, $\left.Q_{\mathrm{B}}=5.4, P=0.05\right)$ but not within the $50-74 \%$ class $(d f=1$, $Q_{\mathrm{B}}=0.38, P=0.48$ ). By grouping these three classes of defoliation, we observed an overall significant effect of tree age on growth response to processionary moth defoliation $\left(d f=1, Q_{\mathrm{B}}=6.0, P=0.02\right)$ with young trees exhibiting larger growth losses than old trees (Fig. 3). Too few replicates were available to allow testing this effect in the 25-49\% class.

\section{Discussion}

The impact of insect defoliation on the growth of evergreen tree species has been extensively studied and most of these studies have concluded that even low levels of defoliation can reduce radial or height growth. In a seminal literature review, Kulman (1971) discussed many cases of damage caused by moth and sawfly conifer defoliators and found that light defoliation induced a significant loss of 10 to $30 \%$ of radial growth. The results of our meta-analysis are consistent with these findings, as we estimated that 5 to $24 \%$ defoliation by processionary moth would reduce pine growth by about $20 \%$. At the other end of the gradient, heavy defoliation had a much greater impact, with 30 to $95 \%$ growth loss (Kulman 1971). Similarly, severe defoliation by the sawflies Diprion pini (L.) on Scots pine (Langstrom et al. 2001; Lyytikäinen-Saarenmaa and Tomppo 2002), Cephalcia lariciphila (Wachtl) on larch (Vejpustkovà and Jaroslav 2006) and Neodiprion abietis (Harr.) on spruce (Parsons et al. 2003) reduced radial growth by 40 to $70 \%$. Radial increment in Scots pine was reduced by about $30 \%$ at the peak of pine looper moth Bupalus piniaria (L.) outbreaks (Straw 1996) and by about $90 \%$ in jack pines following heavy defoliation by Choristoneura pinus (Freeman) (Kulman 1963). Similarly, we found that 76 to $100 \%$ defoliation by processionary moth caused ca. $50 \%$ growth loss in conifers.

Only one study reported a positive effect of processionary moth on pine growth (Barrento et al. 2008), but this may be a false causal effect. Processionary moth females are known to select taller trees for oviposition (Démolin 1969). Young tall trees are likely to exhibit faster growth rates than smaller trees of the same age. If young and tall trees are only very lightly infested by processionary moth, this may not have any detrimental effect on their growth. Thus, growth rates may remain greater for taller defoliated trees than for smaller trees that have not been infested at all (which were considered as control).

There is a broad consensus that the magnitude of growth loss is proportional to the amount of foliage removed by insect herbivores (Kulman 1971; Piene and Little 1990; Gross 1992; Reich et al. 1993). However our metaanalysis revealed an asymptotic relationship, since the effect of processionary moth damage on tree growth levelled out from $50 \%$ of defoliation on (Fig. 2).

In conifers, initial shoot elongation makes use of stored photosynthates from the previous growing season, whereas summer wood growth and needle elongation are mostly dependent on current-year photosynthates (Kulman 1971).
Fig. 2 Effect of the rate of defoliation by processionary moth on growth loss in defoliated trees

\section{Defoliation rate class}

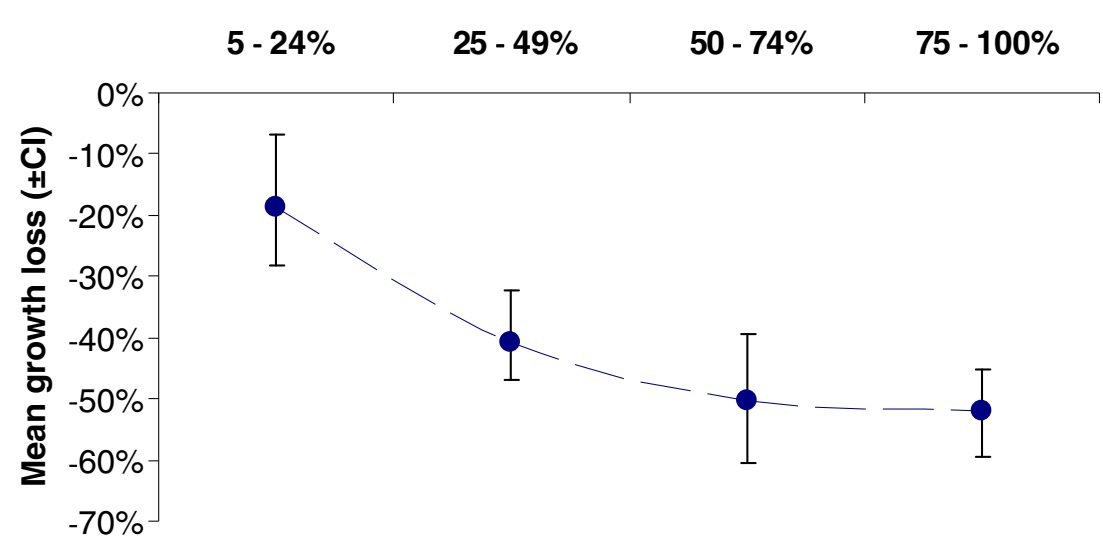


Fig. 3 Effect of tree age on percent growth loss in defoliated trees, for two rates of defoliation by processionary moth. Note that the $25-49 \%$ defoliation class is missing due to lack of data

\section{Defoliation rate class}

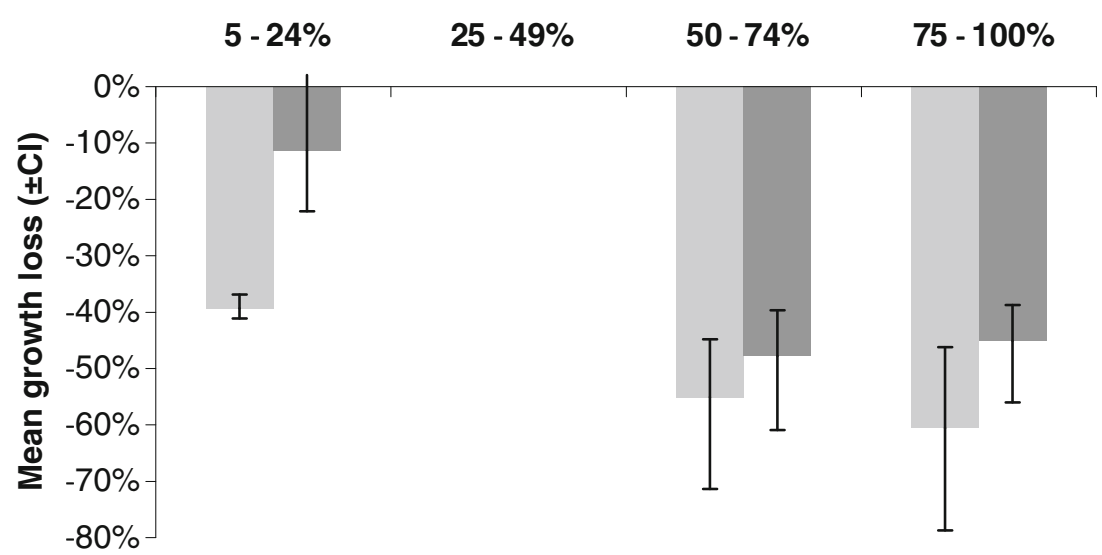

Young trees $\square$ Old trees
According to the carbon/nutrient balance hypothesis (Krause and Raffa 1996), evergreen trees that store a large proportion of their biomass in needles may lose a large proportion of their carbohydrate reserves during defoliation. It has been also suggested that the elimination of old leaves during defoliation induces a shift in carbon allocation to higher priority sinks and, in particular, to the production of new foliage. This would result in carbohydrate shortage for stem diameter growth (Mayfield et al. 2005). For these reasons, conifers would be expected to suffer substantial growth loss in response to insect defoliation, with this impact evident in the same growing season, as observed with processionary moth.

Processionary moth caterpillars feed on pine and cedar needles in autumn and winter. They avoid feeding on young needles unless the mature ones are missing (A. Battisti personal communication). Old foliage contributes a significant part of the tree crown, for example $55 \%$ of tree crown area in maritime pine (Pinus pinaster Ait.) (Porté et al. 2000). The consumption of old foliage is therefore likely to have a significant effect on tree growth (Parsons et al. 2003). However, new foliage produced in spring is known to have higher photosynthetic activity (Porté and Loustau 1997). A small fraction of new foliage regenerated by trees heavily defoliated in the previous winter could then be sufficient to resume growth, which could explain why complete processionary moth defoliation (76-100\%) decreased growth by only about $50 \%$ (Fig. 2).

We found no difference in the effect of processionary moth defoliation on relative growth loss when estimated from circumference and height data. Similarly, Kulman (1971) and Wainhouse (2005) cited several studies in which the impact of insect defoliation on height growth was as severe as that on radial growth. However, we did observe a significant effect of tree age on growth responses to processionary moth defoliation. Kulman (1971) and Wainhouse (2005) argued that young trees are more likely than old trees to die following severe defoliation, but that the growth-reducing effect of defoliation seems to be independent of tree age. Yet, young and older trees differ in term of canopy structure and nutrient storage capacity, and these differences are likely to influence their response to defoliation (Kelly et al. 1995; Straw et al. 2002, 2011). The proportion of older foliage is higher in old than young pine trees (Porté et al. 2000). Because processionary moth caterpillars start feeding on older foliage, for the same percentage defoliation, they will begin feeding on young foliage earlier in younger trees. Since young foliage contributes more to tree growth, the effect of processionary moth defoliation on younger trees is expected to be greater. Larger trees are also expected to mitigate some of the effects of defoliation by using stored nutrient reserves (Niinemets 2010). Although, we compared young and old trees through a meta-analysis of a number of different studies, it would be preferable to test the effect of processionary moth defoliation on the growth of trees of different age classes within the same experimental study, with the same site conditions and processionary moth population levels.

Overall, our meta-analysis, based on all available published papers on the topic, confirms that processionary moth defoliation has a significant impact on pine and cedar growth, even when only a small proportion of the foliage is consumed. Our findings also indicate that growth loss is more pronounced for younger than for older trees and would level out at ca. $50 \pm 10 \%$ for heavily defoliated trees. These results suggest that estimates of processionary moth defoliation could easily be incorporated into tree growth models, to predict the effect of processionary moth outbreaks on carbon sequestration in Mediterranean forests. 
Acknowledgments We would like to thank Andrea Battisti and Manuela Branco who kindly provided us with raw data or copies of their papers. We are also grateful to Anthony O'Grady for rereading the manuscript. This work was supported as a part of the EU-funded FP6 EFORWOOD and FEDER-INTERREG IV Atlantic Space REINFFORCE projects.

\section{References}

Arnaldo P, Chacim S, Lopes D (2010) Effects of defoliation by the pine processionary moth Thaumetopoea pityocampa on biomass growth of young stands of Pinus pinaster in northern Portugal. iForest: Biogeosciences and Forestry 3:159-162. doi:10.3832/ ifor0553-003

Barrento MJ, Santos H, Branco M, Paiva MR (2008) Monitorizaçao da processionaria do pinheiro, Thaumetopoea pityocampa. Monitorizaçao e estimava de estragos, capitulo 2

Battisti A (1988) Host-plant relationships and population dynamics of the pine processionary caterpillar Thaumetopoea pityocampa (Denis and Schiffermüller). J Appl Entomol 105:393-402. doi:10.1111/j.1439-0418.1988.tb00202.x

Carus S (2009) Effects of defoliation caused by the processionary moth on growth of Crimean pines in western Turkey. Phytoparasitica 37:105-114. doi:10.1007/s12600-008-0018-z

Erkan N (2011) Impact of pine processionary moth (Thaumetopoea wilkinsoni Tams) on growth of Turkish red pine (Pinus brutia Ten.). Afr J Agric Res 6:4983-4988

Gachi M, Demolin G, Khemici M, Zamoum M (2005) An evaluation of the radial growth losses of Atlas cedar following defoliation by Thaumetopoea bonjeani in the Belzema massif (Aurès, Algeria). Entomol Res Med For Ecosyst 2:117-122

Graf P, Mzibri M (1994) L'infestation du cèdre de l'Atlas Cedrus atlantica Manetti par la chenille processionnaire du pin au Maroc et son impact sur la productivité. Ann Rech For Maroc 2:613-624

Hodar JA, Castro J, Zamora R (2003) Pine processionary caterpillar Thaumetopoea pityocampa as a new threat for relict Mediterranean Scots pine forests under climatic warming. Biol Conserv 110:123-129

Kanat M, Alma MH, Sivrikaya F (2005) Effect of defoliation by Thaumetopoea pityocampa (Den \& Schiff.) (Lepidoptera: Thaumetopoeiadae) on annual diameter increment of Pinus brutia Ten. in Turkey. Ann For Sci 62:91-94

Lemoine B (1977) Contribution à la mesure des pertes de production causées par la chenille processionnaire Thaumetopoea pityocampa Schiff au pin maritime dans les Landes de Gascogne. Ann For Sci 34:205-214

Markalas S (1998) Biomass production of Pinus pinaster after defoliation by the pine processionary moth (Thaumetopoea pityocampa Schiff.). In: McManus ML, Liebhold AM (eds) Proceedings of Population dynamics, and integrated management of forest defoliating insects. USDA, Forest Service General Technical Report, NE -247: 292-302

Sbabdji M, El Hadi O, Haddad A, Kadik B, Lambs L (2009) Cedar tree growth (Cedrus atlantica Manetti) in Chréa National Park, Algeria, and the influence of defoliation by the pine processionary caterpillar (Thaumetopoea pityocampa Schiff.). Rev Ecol 64:323-332

\section{- other references}

Alfaro RI (1991) Damage assessment and integrated pest management of forest defoliators. For Ecol Manag 39:275-281
Avcí M (2003) Parasitism of egg-batches of the cedar processionary moth Traumatocampa ispartaensis in Turkey. Phytoparasitica 31:118-123. doi:10.1007/BF02980780

Avcí M, Carus S (2005) The impact of cedar processionary moth [Traumatocampa ispartaensis (Doğanlar \& Avcí) (Lepidoptera: Notodontidae)] outbreaks on radial growth of Lebanon cedar (Cedrus libani A. Rich.) trees in Turkey. J Pest Sci 78:91-98. doi:10.1007/s10340-004-0073-2

Battisti A, Stastny M, Netherer S, Robinet C, Schopf A, Roques A, Larsson S (2005) Expansion of geographic range in the pine processionary moth caused by increased winter temperatures. Ecol Appl 15:2084-2096. doi:10.1890/04-1903

Bentz BJ, Regniere J, Fettig CJ, Hansen EM, Hayes JL, Jeffrey HJA, Kelsey RG, Negron JF, Seybold SJ (2010) Climate change and bark beetles of the western United States and Canada: direct and indirect effects. Bioscience 60:602-613. doi:10.1525/bio.2010.60.8.6

Borenstein M, Hedges LV, Higgins JPT, Rothstein HR (2009) Introduction to meta-analysis. Wiley, Chichester

Bouchon J, Toth J (1971) Etude préliminaire sur les pertes de production des pinèdes soumises aux attaques de Thaumetopoea pityocampa Schiff. Ann For Sci 28:323-340

Cadahia D, Insua A (1970) Estimation de los danos producidos por Thaumetopoea pityocampa Sciff., en las respoblaciones de Pinus radiata. OILB, Coloquio de Teruel, pp 14

Calas J (1897) La processionaire du pin. Water For Rev 705-723

Carus S (2004) Impact of defoliation by the pine processionary moth (Thaumetopoea pityocampa) on radial, height and volume growth of Calabrian pine (Pinus brutia) trees in Turkey. Phytoparasitica 32:459-469. doi:10.1007/BF02980440

Carus S (2010) Effect of defoliation by the pine processionary moth (PPM) on radial, height and volume growth of Crimean pine (Pinus nigra) trees in Turkey. J Environ Biol 31:453-460

Chatziphilippidis G, Avtzis N (1994) Growth suppression caused on Pinus brutia Ten. by the defoliating insect Thaumetopoea pityocampa Schiff. Proceedings: IUFRO Meeting on Mountain Silviculture, Spain: 333-341

Démolin G (1969) Comportement des adultes de Thaumetopoea pityocampa Schiff. Dispersion spatiale, importance écologique. Ann For Sci 26:81-102

Devkota B, Schmidt GH (1990) Larval development of Thaumetopoea pityocampa (Den. and Schiff.) (Lepidoptera: Thaumetopoeidae) from Greece as influenced by different host plants under laboratory conditions. J Appl Entomol 109:321-330. doi:10.1111/ j.1439-0418.1990.tb00059.x

Durkaya A, Durkaya B, Dal I (2009) The effects of the pine processionary moth on the increment of Crimean pine trees in Bartin, Turkey. Afr J Biotechnol 8:2356-2361

Dymond CC (2010) Future spruce budworm outbreak may create a carbon source in eastern Canadian forests. Ecosystems 13:917931. doi:10.1890/1051-0761(1999) 009[0526:AYRAOC] 2.0.CO;2

Gross HL (1992) Impact analysis for a jack pine budworm infestation in Ontario. Can J For Res 22:818-831. doi:10.1139/x92-111

Gurevitch J, Hedges LV (1993) Meta-analysis: combining the results of independent studies in experimental ecology. In: Scheiner SM, Gurevitch J (eds) The design and analysis of ecological experiments. Oxford University Press, New York, pp 378-398

Gurevitch J, Hedges LV (1999) Statistical issues in ecological metaanalyses. Ecology 80:1142-1149

Halperin J (1990) Life history of Thaumetopoea spp. (Lep., Thaumetopoeidae) in Israel. J Appl Entomol 110:1-6. doi:10.1111/j.14390418.1990.tb00088.x

Hedges LV, Gurevitch J, Curtis PS (1999) The meta-analysis of response ratios in experimental ecology. Ecology 80:1150-1156. doi:10.1890/0012-9658(1999) 080[1150:TMAORR]2.0.CO;2 
Hernandez JMM, Anta MB, Díaz MJL (2008) Inflencia de la calidad de estacion en el crecimiento de Pinus pinaster y $P$. radiata tras una defoliacion de procesionaria. Cuad Soc Esp For 26:67-71

Hyvönen R, Ågren GI, Linder S, Persson T, Cotrufo MF, Ekblad A, Freeman M, Grelle A, Janssens IA, Jarvis PG, Kellomäki S, Lindroth A, Loustau D, Lundmark T, Norby RJ, Oren R, Pilegaard K, Ryan MG, Sigurdsson BD, Strömgren M, van Oijen M, Wallin G (2007) The likely impact of elevated [CO2], nitrogen deposition, increased temperature and management on carbon sequestration in temperate and boreal forest ecosystems: a literature review. New Phytol 173:463-480. doi:10.1111/j.14698137.2007.01967.x

Joly R (1976) Les Insectes Ennemis des Pins. Ecole Nationale du Génie Rural, des Eaux et des Forêts, Nancy

Kelly JM, Samuelson L, Edwards G, Hanson P, Kelting D, Mays A, Wullschleger S (1995) Are seedlings reasonable surrogates for trees? An analysis of ozone impacts on Quercus rubra. Water Air Soil Pollut 85:1317-1324. doi:10.1007/BF00477164

Krause SC, Raffa KF (1996) Differential growth and recovery rates following defoliation in related deciduous and evergreen trees. Trees 10:308-316. doi:10.1007/BF02340777

Kulman HM (1963) Distribution and effects of jack-pine budworm defoliation. For Sci 9:146-157

Kulman HM (1971) Effects of insect defoliation on growth and mortality of trees. Annu Rev Entomol 16:289-324. doi:10.1146/ annurev.en.16.010171.001445

Kurz WA, Dymond CC, Stinson G, Rampley GJ, Neilson ET, Carroll AL, Ebata T, Safranyik L (2008) Mountain pine beetle and forest carbon feedback to climate change. Nature 452:987-990. doi:10.1038/nature06777

Laurent-Hervouët N (1986) Mesure des pertes de croissance radiale sur quelques espèces de Pinus dues à deux défoliateurs forestiers. I Cas de la processionnaire du pin en région méditerranéenne. Ann For Sci 43:239-262

Langstrom B, Annila E, Hellqvist C, Varama M, Niemela P (2001) Tree mortality needle biomass recovery and growth losses in Scots pine following defoliation by Diprion pini and subsequent attack by Tomicus piniperda. Scand J For Res 16:342-353. doi:10.1080/02827580118325

Logan JA, Régnière J, Powell JA (2003) Assessing the impacts of global warming on forest pest dynamics. Front Ecol Environ 1:130-137. doi:10.1890/1540-9295(2003) 001[0130:ATIOGW] 2.0.CO;2

Lyytikäinen-Saarenmaa P, Tomppo E (2002) Impact of sawfly defoliation on growth of Scots pine (Pinus sylvestris) (Pinaceae) and associated economic losses. Bull Entomol Res 93:137-140. doi:10.1079/BER2002154

Luyssaert S, Ciais P, Piao SL, Schulze ED, Jung M, Zaehle S, Schelhaas MJ, Reichstein M, Churkina G, Papale D, Abril G, Beer C, Grace J, Loustau D, Matteucci G, Magnani F, Nabuurs GJ, Verbeeck H, Sulkava M, van der WERF GR, Janssens IA, members of the CARBOEUROPE-IP SYNTHESIS TEAM (2010) The European carbon balance. Part 3: forests. Glob Chang Biol 16:1429-1450. doi:10.1111/j.1365-2486.2009.02056.x

Masutti L, Battisti A (1990) Thaumetopoea pityocampa (Den. \& Schiff.) in Italy Bionomics and perspectives of integrated control12. J Appl Entomol 110:229-234. doi:10.1111/j.14390418.1990.tb00117.x

Mayfield AE III, Douglas CA, Briggs RD (2005) Radial growth impact of pine false webworm defoliation on eastern white pine. Can J For Res 35:1071-1086. doi:10.1139/x05-040

Morris WF, Hufbauer RA, Agrawal AA, Bever JD, Borowicz VA, Gilbert GS, Maron JL, Mitchell CE, Parker IM, Power AG, Torchin ME, Vázquez DP (2007) Direct and interactive effects of enemies and mutualists on plant performance: a meta-analysis. Ecology 88:1021-1029. doi:10.1890/06-0442
Nabuurs GJ, Thurig E, Heidema N, Armolaitis K, Biber P, Cienciala E, Kaufmann E (2008) Hotspots of the European forests carbon cycle. For Ecol Manag 256:194-200

Nemani RR, Keeling CD, Hashimoto H, Jolly WM, Piper SC, Tucker CJ, Myneni RB, Running SW (2003) Climate-driven increases in global terrestrial net primary production from 1982 to 1999. Science 300:1560-1563. doi:10.1126/science. 1082750

Netherer S, Schopf A (2010) Potential effects of climate change on insect herbivores in European forests-general aspects and the pine processionary moth as specific example. For Ecol Manag 259:831-838

Niinemets U (2010) Responses of forest trees to single and multiple environmental stresses from seedlings to mature plants: past stress history, tolerance and acclimation. For Ecol Manag 260:16231639. doi:10.1016/j.foreco.2010.07.054

Parsons K, Quiring D, Piene H, Farrell J (2003) Temporal patterns of balsam fir sawfly defoliation and growth loss in young balsam fir. For Ecol Manag 184:33-46. doi:10.1016/S0378-1127(03)001452

Pestaña M, Santolamazza-Carbone S (2010) Defoliation negatively affects plant growth and the ectomycorrhizal community of Pinus pinaster in Spain. Oecologia 165:723-733. doi:10.1007/s00442010-1760-8

Piene H, Little CHA (1990) Spruce budworm defoliation and growth loss in young balsam fir: artificial defoliation of potted trees. Can J For Res 20:902-909. doi:10.1139/x90-121

Pinkard EA, Battaglia M, Roxburgh S, O’Grady AP (2011) Estimating forest net primary production under changing climate: adding pests into the equation. Tree Physiol 31:686-699. doi:10.1093/ treephys/tpr054

Porté A, Loustau D (1997) Variability of the photosynthetic characteristics of mature needles within the crown of a 25-year-old Pinus pinaster. Tree Physiol 18:223-232

Porté A, Bosc A, Champion I, Loustau D (2000) Estimating the foliage area of maritime pine (Pinus pinaster Ait) branches and crowns with application to modelling the foliage area distribution in the crown. Ann For Sci 57:73-86

Quentin AG, Pinkard EA, Beadle CL, Wardlaw TJ, O'Grady AP, Paterson S, Mohammed CL (2010) Do artificial and natural defoliation have similar effects on physiology of Eucalyptus globulus Labill. seedlings? Ann For Sci 67:203. doi:10.1051/ forest/2009096

Reich PB, Walters MB, Krause SC, Vanderklein DW, Raffa KF, Tabone T (1993) Growth, nutrition and gas exchange of Pinus resinosa following artificial defoliation. Trees 7:67-77. doi:10.1007/BF00225472

Robinet C, Baier P, Pennerstorfer J, Schopf A, Roques A (2007) Modelling the effects of climate change on the potential feeding activity of Thaumetopoea pityocampa (Den. and Schiff.) (Lep., Notodontidae) in France. Glob Ecol Biogeogr 16:460-471. doi:10.1111/j.1466-8238.2006.00302.x

Rosenberg MS (2005) The file-drawer problem revisited: a general weighted method for calculating fail-safe numbers in meta-analysis. Evolution 59:464-468. doi:10.1111/j.0014-3820.2005.tb01004.x

Rosenberg MS, Adams DC, Gurevitch J (2000) MetaWin: statistical software for meta-analysis. Version 2.0. Sinauer Associates, Sunderland

Straw NA (1996) The impact of pine looper moth, Bupalus piniaria L. (Lepidoptera; Geometridae) on the growth of Scots pine in Tentsmuir Forest, Scotland. For Ecol Manag 87:209-232

Straw NA, Fielding NJ, Green G, Price J (2002) The impact of green spruce aphid, Elatobium abietinum (Walker), on the growth of young Sitka spruce in Hafren forest, Wales: delayed effects on needle size limit wood production. For Ecol Manag 157:267-283

Straw N, Fielding N, Green G, Price J, Williams D (2011) Defoliation and growth relationships for mid-rotation Sitka 
spruce attacked by the green spruce aphid, Elatobium abietinum (Walker) (Homoptera: Aphididae). For Ecol Manag 262:1223-1235

Twery MJ (1990) Effects of defoliation by gypsy moth. In: Twery MJ, Smith SI (ed) Proceedings USDA InterAgency Gypsy Moth Research Review, East Windsor, CT, pp 27-39
Vejpustkovà M, Jaroslav H (2006) Impact of defoliation caused by the sawfly Cephalcia lariciphila (Hymenoptera: Pamphilidae) on radial growth of larch (Larix decidua Mill.). Eur J For Res 125:391-396

Wainhouse D (2005) Ecological methods in forest pest management. Oxford University Press, New York 